\title{
A preliminary study of iron isotope fractionation in marine invertebrates (chitons, Mollusca) in near-shore environments
}

\author{
S. Emmanuel ${ }^{1}$, J. A. Schuessler ${ }^{2}$, J. Vinther ${ }^{3}$, A. Matthews ${ }^{1,4}$, and F. von Blanckenburg ${ }^{2}$ \\ ${ }^{1}$ Institute of Earth Sciences, The Hebrew University of Jerusalem, Jerusalem, Israel \\ ${ }^{2}$ Helmholtz Centre Potsdam, German Research Centre for Geosciences GFZ, Section 3.4, Earth Surface Geochemistry, \\ Potsdam, Germany \\ ${ }^{3}$ School of Earth Sciences, University of Bristol, Bristol, UK \\ ${ }^{4}$ National Natural History Collections, Institute of Earth Sciences, The Hebrew University of Jerusalem, Jerusalem, Israel
}

Correspondence to: S. Emmanuel (swemmanuel@gmail.com)

Received: 27 February 2014 - Published in Biogeosciences Discuss.: 11 April 2014

Revised: 13 August 2014 - Accepted: 28 August 2014 - Published: 8 October 2014

\begin{abstract}
Chitons (Mollusca) are marine invertebrates that produce radulae (teeth or rasping tongues) containing high concentrations of biomineralized magnetite and other ironbearing minerals. As Fe isotope signatures are influenced by redox processes and biological fractionation, Fe isotopes in chiton radulae might be expected to provide an effective tracer of ambient oceanic conditions and biogeochemical cycling. Here, in a pilot study to measure Fe isotopes in marine invertebrates, we examine $\mathrm{Fe}$ isotopes in modern marine chiton radulae collected from different locations in the Atlantic and Pacific oceans to assess the range of isotopic values, and to test whether or not the isotopic signatures reflect seawater values.

Values of $\delta^{56} \mathrm{Fe}$ (relative to IRMM-014) in chiton teeth range from -1.90 to $0.00 \%$ ( $\pm 0.05 \%$ o $(2 \sigma)$ uncertainty in $\delta^{56} \mathrm{Fe}$ ), probably reflecting a combination of geographical control and biological fractionation processes. Comparison with published local surface seawater Fe isotope data shows a consistent negative offset of chiton teeth Fe isotope compositions relative to seawater. Strikingly, two different species from the same locality in the North Pacific (Puget Sound, Washington, USA) have distinct isotopic signatures. Tonicella lineata, which feeds on red algae in the sublittoral zone, has a mean $\delta^{56} \mathrm{Fe}$ of $-0.65 \pm 0.26 \%$ o ( $2 \sigma, 3$ specimens), while Mopalia muscosa, which feeds on both green and red algae in the eulittoral zone, shows lighter isotopic values with a mean $\delta^{56} \mathrm{Fe}$ of $-1.47 \pm 0.98 \%$ ( $2 \sigma, 5$ specimens). Three possible pathways are proposed to account for the different isotopic signatures: (i) physiologically controlled processes within the chitons that lead to species-dependent fractionation; (ii) diet-controlled variability due to different $\mathrm{Fe}$ isotope
\end{abstract}

fractionation in the red and green algal food sources; and (iii) environmentally controlled fractionation that causes variation in the isotopic signatures of bioavailable $\mathrm{Fe}$ in the different tidal regions. Our preliminary results suggest that while chitons are not simple recorders of the ambient seawater $\mathrm{Fe}$ isotopic signature, Fe isotopes provide valuable information concerning $\mathrm{Fe}$ biogeochemical cycling in near-shore environments, and may potentially be used to probe sources of $\mathrm{Fe}$ recorded in different organisms.

\section{Introduction}

Iron plays a critical role in controlling biological productivity in the oceans (Martin et al., 1990; De Baar et al., 1995; Coale et al., 1996), and understanding the biogeochemical cycling of Fe is therefore key in reconstructing the history of life on Earth. One potentially rewarding way to reconstruct past marine conditions is to examine variations in the isotopic signature of iron. Changes to $\mathrm{Fe}$ isotope ratios occur due to shifts in redox state, chemical bonding environment, adsorption properties, and microbial and organic-ligand bonding processes (e.g. Matthews et al., 2001; Zhu et al., 2002; Beard et al., 2003a, b; Brantley et al., 2004; Croal et al., 2004; Welch et al., 2003; Johnson et al., 2005; Teutsch et al., 2005; Crosby et al., 2007; Matthews et al., 2008), and precise measurements of these isotopes could yield vital information about geochemical and ecological conditions in both presentday and past environments. 
While studies have examined isotopic variations of $\mathrm{Fe}$ in marine rocks (e.g. Matthews et al. 2004; Staubwasser et al., 2006; Severmann et al., 2006), marine organisms that accumulate significant amounts of $\mathrm{Fe}$ could also prove to be good environmental recorders. One group of marine molluscs that might fulfill this role is chitons (Fig. 1a and b). Belonging to the class Polyplacophora, these molluscs graze on algae on the surface of rocks and other hard substrates in the near-shore coastal environment using radulae (or rasping tongues) made up of teeth impregnated with magnetite and other iron-bearing minerals, such as ferrihydrite, goethite, and lepidocrocite (e.g. Lowenstam, 1962a; Towe and Lowenstam, 1967; Lowenstam and Kirschvink, 1996; Lowenstam and Weiner, 1989). Due to their high level of iron accumulation, the $\mathrm{Fe}$ isotopic signature of modern chiton radulae might be expected to reflect ambient oceanic environments.

However, a number of factors may influence the isotopic composition of $\mathrm{Fe}$ accumulated in chiton teeth at any given location. Being primarily herbivorous, they extract nutrients from marine algae, which in turn absorb nutrients directly from seawater. As the isotopic composition of $\mathrm{Fe}$ in seawater can vary spatially due to variations in the relative contributions of different sources, including continental runoff, aerosols, hydrothermal fluids, and oceanic crust alteration (Sharma et al., 2001; Anbar and Rouxel, 2007; Johnson et al., 2008; Homoky et al., 2012), the isotopic value recorded in invertebrate teeth could therefore change with geographical location. In addition, utilization by marine organisms and associated biological fractionation may also play an important role in determining Fe isotope compositions. Bacteria are known to form isotopically light magnetite during dissimilatory microbial reduction of Fe(III) oxyhydroxides (Johnson et al., 2005); other organisms, such as algae and even the chitons themselves, could also fractionate Fe isotopes as a result of biomineralization processes. Although Fe isotope signatures in higher organisms have been studied (e.g. Walczyk and von Blanckenburg, 2002; Hotz, 2011), little is currently known about the natural variation of metal isotopes in marine invertebrates or the influence that biological fractionation and environmental factors, such as geographical location and diet, may have on those signatures.

Here, in a preliminary study, we examine Fe isotopes in modern marine chitons collected from different locations in the Atlantic and Pacific oceans to determine the range of isotopic values that might be encountered and whether or not these isotopic signatures reflect seawater values. Furthermore, by comparing two different species that were collected at the same geographical location but have very different feeding habits, we make a first attempt to isolate the potential impact of diet on metal isotopic signatures. While our findings are not definitive, the small new data set sheds light on the possible pathways of Fe biogeochemical cycling in near-shore environments, highlighting important new directions for future research.

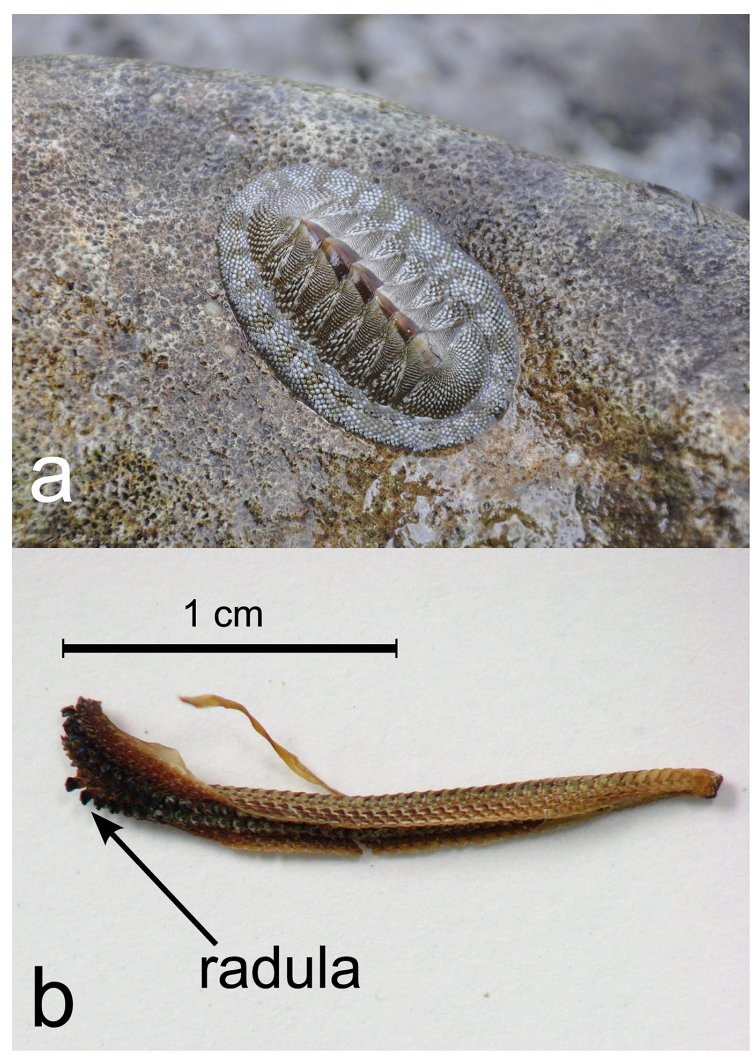

Figure 1. (a) Chiton tuberculatus in the eulittoral zone, and (b) a radula sac containing the magnetite-capped teeth, indicated by the arrow. C. tuberculatus specimens are typically $14-80 \mathrm{~mm}$ in length (Glynn, 1970), and the one shown in (a) is approximately $50 \mathrm{~mm}$ long.

\section{Methods}

Ideally, chiton samples would have been obtained from a field campaign that collected specimens from different locations around the world. However, in this preliminary study such an approach was not feasible, and instead samples were selected from the collections at the Peabody Museum of Natural History at Yale University. The samples were collected in the early 1900s and preserved in formalin, which primarily acts as an antimicrobial agent; although the effect of prolonged exposure of $\mathrm{Fe}$ oxides to formalin is not known, we assume no mineralogical or isotopic changes to have occurred in the samples. A total of 24 individual chiton specimens representing 5 different species from 4 different geographical locations were selected for analysis. A summary of the samples is given in Table 1. To represent high- and low-latitude sites from the Atlantic Ocean, chitons from Bermuda and New Brunswick, Canada, were sampled; from the Pacific Ocean, samples from Panama and Washington State, USA, were selected. In addition, from the Washington locality, two different species that feed predominantly on green algae and red algae - Tonicella lineata and Mopalia 
Table 1. Summary of analysed chiton samples.

\begin{tabular}{|c|c|c|c|c|c|c|c|c|c|}
\hline Species & $\begin{array}{l}\text { Individual } \\
\text { specimens }\end{array}$ & Locality & Ecology & Specimen ID & $\begin{array}{r}\delta^{56} \mathrm{Fe} \\
\% \circ\end{array}$ & $\begin{array}{r}2 \mathrm{SE} \\
\% 0\end{array}$ & $\begin{array}{r}\delta^{57} \mathrm{Fe} \\
\% \circ\end{array}$ & $\begin{array}{r}2 \mathrm{SE} \\
\% o\end{array}$ & $n$ \\
\hline $\begin{array}{l}\text { Tonicella } \\
\text { lineata }\end{array}$ & 5 & Puget Sound, WA, USA & $\begin{array}{l}\text { Sublittoral, } \\
\text { red algae }\end{array}$ & $\begin{array}{l}\text { YPM-12716-01 } \\
\text { YPM-12716-02 } \\
\text { YPM-12716-03 } \\
\text { YPM-12720-04 } \\
\text { YPM-12720-05 }\end{array}$ & $\begin{array}{l}-0.57 \\
-0.73 \\
-0.56 \\
-0.54 \\
-0.83\end{array}$ & $\begin{array}{l}0.04 \\
0.05 \\
0.05 \\
0.04 \\
0.05\end{array}$ & $\begin{array}{l}-0.84 \\
-1.07 \\
-0.83 \\
-0.82 \\
-1.22\end{array}$ & $\begin{array}{l}0.07 \\
0.07 \\
0.05 \\
0.07 \\
0.06\end{array}$ & $\begin{array}{l}4 \\
4 \\
5 \\
5 \\
4\end{array}$ \\
\hline $\begin{array}{l}\text { Mopalia } \\
\text { muscosa }\end{array}$ & 3 & Puget Sound, WA, USA & $\begin{array}{l}\text { Eulittoral, } \\
\text { green algae }\end{array}$ & $\begin{array}{l}\text { YPM-12718-06 } \\
\text { YPM-12718-07 } \\
\text { YPM-12718-08 }\end{array}$ & $\begin{array}{l}-1.58 \\
-1.90 \\
-0.94\end{array}$ & $\begin{array}{l}0.04 \\
0.02 \\
0.04\end{array}$ & $\begin{array}{l}-2.33 \\
-2.81 \\
-1.39\end{array}$ & $\begin{array}{l}0.06 \\
0.03 \\
0.04\end{array}$ & $\begin{array}{l}5 \\
6 \\
5\end{array}$ \\
\hline $\begin{array}{l}\text { Tonicella } \\
\text { marmorea }\end{array}$ & 8 & $\begin{array}{l}\text { Grand Manan Island, } \\
\text { New Brunswick, Canada }\end{array}$ & $\begin{array}{l}\text { Sublittoral, } \\
\text { red algae }\end{array}$ & YPM-12760-09 & -1.10 & 0.05 & -1.61 & 0.06 & 5 \\
\hline $\begin{array}{l}\text { Chiton } \\
\text { stokessi }\end{array}$ & 5 & Panama & $\begin{array}{l}\text { Eulittoral, } \\
\text { green algae }\end{array}$ & $\begin{array}{l}\text { YPM-5176-10 } \\
\text { YPM-5176-11 } \\
\text { YPM-5176-12 } \\
\text { YPM-5176-13 } \\
\text { YPM-5176-14 }\end{array}$ & $\begin{array}{l}-1.11 \\
-1.26 \\
-0.73 \\
-1.29 \\
-1.06\end{array}$ & $\begin{array}{l}0.03 \\
0.01 \\
0.04 \\
0.06 \\
0.05\end{array}$ & $\begin{array}{l}-1.63 \\
-1.86 \\
-1.03 \\
-1.89 \\
-1.54\end{array}$ & $\begin{array}{l}0.05 \\
0.03 \\
0.07 \\
0.06 \\
0.09\end{array}$ & $\begin{array}{l}6 \\
6 \\
5 \\
4 \\
4\end{array}$ \\
\hline $\begin{array}{l}\text { Chiton } \\
\text { tuberculatus }\end{array}$ & 3 & Bermuda & $\begin{array}{l}\text { Eulittoral, } \\
\text { green algae }\end{array}$ & $\begin{array}{l}\text { YPM-12739-15 } \\
\text { YPM-12739-16a } \\
\text { YPM-12739-16b } \\
\text { YPM-12739-17 }\end{array}$ & $\begin{array}{r}-0.38 \\
0.00 \\
-0.28 \\
-0.28\end{array}$ & $\begin{array}{l}0.01 \\
0.05 \\
0.02 \\
0.05\end{array}$ & $\begin{array}{r}-0.54 \\
0.00 \\
-0.40 \\
-0.40\end{array}$ & $\begin{array}{l}0.03 \\
0.09 \\
0.04 \\
0.07\end{array}$ & $\begin{array}{l}6 \\
4 \\
8 \\
5\end{array}$ \\
\hline
\end{tabular}

Iron isotope data are reported as per mill deviation relative to the international reference material IRMM-014. Mean values of $n$ replicate analyses of the same analyte solution are reported with their $95 \%$ confidence intervals $(2 \mathrm{SE}=t \cdot \mathrm{SD} / \sqrt{ } n$, where $t$ is the correction factor from Student $t$ distribution at $95 \%$ probability). Uncertainties in $\delta^{56} \mathrm{Fe}$ and $\delta^{57} \mathrm{Fe}$ associated with the entire Fe isotope analytical procedure are estimated to be $\pm 0.05 \% \circ(2 \sigma)$ and $\pm 0.08 \%$ o $(2 \sigma)$, respectively (see text).

muscosa, respectively - were selected for comparison. Of the five species investigated in this study, three inhabit the eulittoral (intertidal) zone, while two are found in the sublittoral (neritic zone). The eulittoral zone is characterized by tidal activity and extends from the low tide line to the high tide line leading to periodic dry and flood periods. The sublittoral zone starts immediately below the eulittoral zone and is permanently underwater. Sunlight penetrates to the seafloor in the eulittoral zone; therefore both the eulittoral and sublittoral zones are within the photic zone.

The protocol for sample preparation involved dissection of the chitons to extract the radula sac containing the magnetitecapped teeth; a magnetic separation technique was used to separate the radula from the organic matter. A single radula is made of two symmetric rows of teeth (Fig. 1a). The total number and size of teeth of each radula can vary depending on the species. Here, each isotopic analysis (Table 1) represents a homogenized sample comprising all teeth of a complete radula for each individual specimen. Due to the small size of the radulae for T. marmorea from New Brunswick, the teeth from eight individual specimens were combined and homogenized to produce one isotopic measurement. One sample (YPM12739-16) was processed in duplicate, and a total of 18 values are reported here.
After separation, the radulae were then processed in a clean-room facility, where they were digested using ultrapure concentrated $\mathrm{HCl}$; hydrogen peroxide was also added to remove any residual organic material. The digested sample solution was evaporated on a hot plate and re-dissolved in $6 \mathrm{M} \mathrm{HCl}$ before being passed through chromatographic columns to isolate $\mathrm{Fe}$ (Zhu et al., 2002; Archer and Vance, 2004). Purity of samples and quantitative recovery of iron after the column separation procedure was verified by inductively coupled plasma mass spectrometry (ICP-MS; Agilent $7500 \mathrm{cx}$ ) analyses. Total $\mathrm{Fe}$ amounts ranged from 30 to $840 \mu \mathrm{g}$. Purity of Fe analyte solutions was found to be better than $99 \%$, which is sufficient for accurate Fe isotope analyses using the method described below (Schoenberg and von Blanckenburg, 2005). It is worth noting that efficient separation of $\mathrm{Cr}$ and $\mathrm{Ni}$ from $\mathrm{Fe}$ was achieved, eliminating spectral interferences of ${ }^{54} \mathrm{Cr}$ on ${ }^{54} \mathrm{Fe}$ and ${ }^{58} \mathrm{Ni}$ on ${ }^{58} \mathrm{Fe}$ during mass-spectrometric measurements of $\mathrm{Fe}$ isotope ratios. The procedure was also tested by processing the reference material IRMM-014 repeatedly through the same chromatographic separation protocol as the samples. This method yielded a $\delta^{56} \mathrm{Fe}$ value for IRMM-014 of $-0.03 \pm 0.02$ ( $2 \mathrm{SE}$, $n=16$ ), which is identical to the unprocessed IRMM-014, within the external uncertainty of the method. Prior to isotope analysis, samples were dissolved in $0.3 \mathrm{M} \mathrm{HNO}_{3}$ and diluted to about $2 \mu \mathrm{g} \mathrm{mL}^{-1} \mathrm{Fe}$, matching the ion beam intensities 
( $\sim 20 \mathrm{~V}$ on ${ }^{56} \mathrm{Fe} ; 10^{11} \Omega$ amplifier, $\mathrm{H}$ cones) of the bracketing standard (IRMM-014) within $10 \%$. The Fe isotopic analyses were performed on a total set of 18 chiton samples using a Thermo Scientific Neptune multi-collector inductively coupled plasma mass spectrometer (MC-ICP-MS) at GFZ Potsdam in Germany. The mass spectrometer is equipped with a Neptune Plus jet interface pump and an ESI Apex-Q desolvating system (without membrane) with a $\sim 50 \mu \mathrm{L} \mathrm{min}-1$ PFA nebulizer for sample introduction. Iron isotope analyses were performed in "medium" mass resolution mode (mass resolving power $\mathrm{m} / \Delta \mathrm{m}(5,95 \%)>7600)$ to resolve all $\mathrm{Fe}$ isotopes from polyatomic interferences (mainly ArO, $\mathrm{ArOH}$, and ArN; see Weyer and Schwieters, 2003, for details). Potential interferences from of ${ }^{54} \mathrm{Cr}$ on ${ }^{54} \mathrm{Fe}$ and ${ }^{58} \mathrm{Ni}$ on ${ }^{58} \mathrm{Fe}$ were monitored at masses ${ }^{52} \mathrm{Cr}$ and ${ }^{60} \mathrm{Ni}$ and corrections to $\mathrm{Fe}$ isotope ratios were made according to the method described in Schoenberg and von Blanckenburg (2005). In this study, corrections made to the data are insignificant compared to the analytical uncertainty, due to the low impurity levels of $\mathrm{Cr}$ and $\mathrm{Ni}$, i.e. ${ }^{54} \mathrm{Cr} /{ }^{54} \mathrm{Fe}<0.005 \%$ and ${ }^{58} \mathrm{Ni} /{ }^{58} \mathrm{Fe}<0.5 \%$. The sample-standard bracketing method was used for mass bias correction (using IRMM-014 as bracketing standard), following the measurement procedure and data acceptance criteria of Schoenberg and von Blanckenburg (2005), and results are reported relative to the international reference material IRMM-014 using the delta notation:

$\delta^{56} \mathrm{Fe}=\left(\frac{\left[\frac{56 \mathrm{Fe}}{{ }^{54} \mathrm{Fe}}\right]_{\text {sample }}}{\left[\frac{56 \mathrm{Fe}}{{ }^{54} \mathrm{Fe}}\right]_{\text {standard }}}-1\right) \times 1000$.

Between four and eight repeat measurements of each purified sample solution were performed in two or three independent analytical sessions; the mean $\delta$ value of $n$ replicates is reported in Table 1 together with the $95 \%$ confidence interval $(2 \mathrm{SE}=t \times \mathrm{SD} / \sqrt{ } n$, where $t$ is the correction factor for small numbers of $n$ from Student's $t$ distribution at $95 \%$ probability). For data quality control, measurement accuracy and precision was assessed by repeated analyses of an inhouse working standard (HanFe: a pure Fe solution used as a control standard) in each analytical session, and four aliquots of the reference material IRMM- $014\left(\delta^{56} \mathrm{Fe} \equiv 0 \%\right.$ ) were independently processed through the same chromatographic separation protocol as the samples. The uncertainty associated with the Fe separation and isotope analysis of IRMM-14 with $\delta^{56} \mathrm{Fe}=-0.03 \pm 0.05 \%$ o $(2 \sigma=2$ standard deviations of the mean) and $\delta^{57} \mathrm{Fe}=0.04 \pm 0.08 \%$ o $(2 \sigma)$ agrees well with the mass-spectrometric repeatability estimated over the course of this study from the HanFe standard with $\delta^{56} \mathrm{Fe}=$ $+0.27 \pm 0.05 \%$ o $(2 \sigma, n=59)$ and $\delta^{57} \mathrm{Fe}$ of $+0.39 \pm 0.08 \% o$ $(2 \sigma)$, as well as from the data set of the 18 investigated chiton teeth samples ( $\Sigma n_{i}=91$ measured $\delta$ values) according to $2 \cdot \sqrt{ }\left\{\left[\Sigma\left(x_{i}-x_{j-\text { mean }}\right)^{2}\right] /\left[\Sigma\left(n_{i, j}-1\right)\right]\right\}$, for the $j$ th chiton sample with a mean isotope composition $x_{j-\text { mean }}$ determined from $i$ replicate analyses $x_{i}$, yielding $\pm 0.05(2 \sigma)$ and \pm 0.08
$(2 \sigma)$ for $\delta^{56} \mathrm{Fe}$ and $\delta^{57} \mathrm{Fe}$, respectively. Hence, the overall uncertainty estimate of the reported $\delta^{56} \mathrm{Fe}$ and $\delta^{57} \mathrm{Fe}$ values is $\pm 0.05 \%$ o $(2 \sigma)$ and $\pm 0.08 \%$ o $(2 \sigma)$, respectively.

\section{Results and discussion}

\subsection{Fe isotopic measurements in chiton teeth}

The $\delta^{56} \mathrm{Fe}$ values measured in the samples cover a wide range, varying from -1.90 to $0.00 \%$ (Fig. 2). Although the overall range is quite large, the chiton specimens from each of the different regions cluster reasonably close together, with each chiton group possessing a distinct isotopic composition: Chiton tuberculatus from the subtropical North Atlantic (Bermuda) has a mean Fe isotope signature of $\delta^{56} \mathrm{Fe}=-0.23 \pm 0.32 \%$ o ( $2 \sigma, 3$ specimens $)$, while the value for T. marmorea from the North Atlantic (Grand Manan Island, New Brunswick, Canada) is $-1.10 \%$. Chiton stokessi from the South Pacific (Panama) has a mean $\delta^{56} \mathrm{Fe}$ value of $-1.09 \pm 0.44 \%$ o ( $2 \sigma, 5$ specimens), while $T$. lineata and $M$. muscosa from the North Pacific (Puget Sound, Washington)

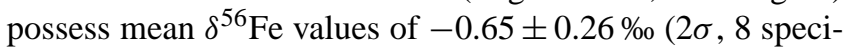
mens) and $-1.47 \pm 0.98 \%$ ( $2 \sigma, 5$ specimens $)$, respectively,

Such large variation in isotopic signatures between the chitons in the different locations might be expected given the widely varying $\delta^{56} \mathrm{Fe}$ values reported for dissolved $\mathrm{Fe}$ (filtered $<0.45 \mu \mathrm{m}$ ) in seawater in different oceans. Isotopically heavy values in $\delta^{56} \mathrm{Fe}$ from +0.01 to $+0.58 \%$ o have been measured at different locations in the Pacific Ocean (Lacan et al., 2010; Radic et al., 2011). Also, at different depths within the water column, significant variations in $\mathrm{Fe}$ isotope compositions have been reported in the Pacific Ocean: in the San Pedro Basin in the North Pacific, $\delta^{56} \mathrm{Fe}$ values ranged from $0.00 \%$ at the surface to extremely negative values of $-1.82 \%$ at a depth of $900 \mathrm{~m}$. Large variations have also been reported in the Atlantic Ocean: $\delta^{56} \mathrm{Fe}$ values in the range of -0.14 to $+0.23 \%$ o have been reported for the Atlantic Section of the Southern Ocean (Lacan et al., 2008, 2010), while values of -0.13 to $0.27 \%$ o have been measured in the southeastern Atlantic (Lacan et al., 2010); in the North Atlantic $\delta^{56} \mathrm{Fe}$ values varying between +0.30 and $+0.71 \%$ o have been reported in some studies (John and Adkins, 2010; John and Adkins, 2012; Lacan et al., 2010), while isotopic signatures in the range of -0.90 to $+0.10 \%$ have also been reported off the northeastern coast of North America (Rouxel and Auro, 2010). Such geographical dependence of seawater isotopic signatures is generally thought to be due to changes in the balance of different inputs and the influence of utilization of $\mathrm{Fe}$ as a nutrient by marine organisms (e.g. Radic et al., 2011). Negative seawater values could be due to dissimilatory iron reduction or high local flux from continental runoff flux (Anbar and Rouxel, 2007), while positive values have been interpreted as indicative of non-reductive dissolution of sediments (Radic et al., 2011). 


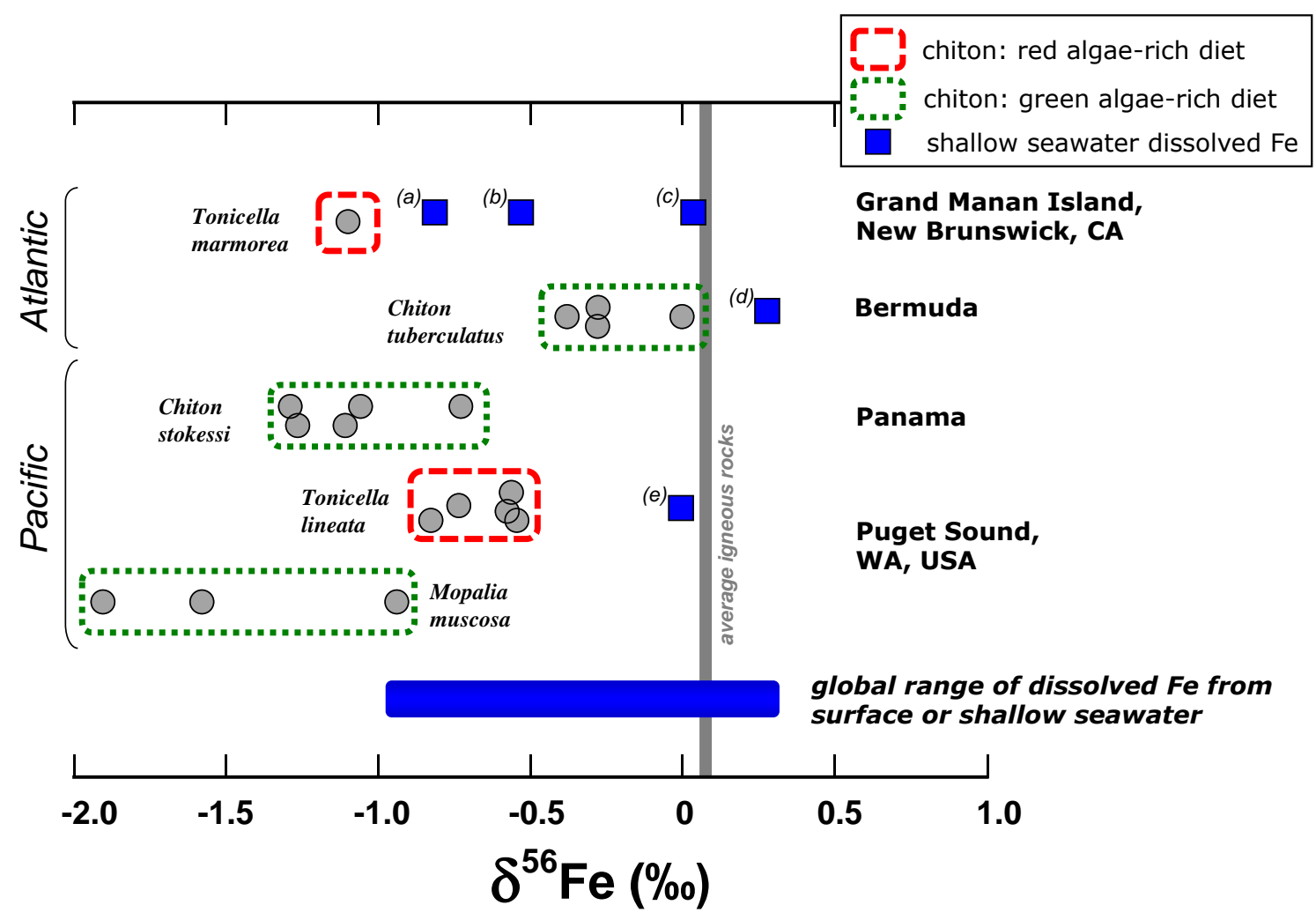

Figure 2. Fe isotope signatures of 18 chiton teeth analyses (grey circles). Analytical uncertainties in $\delta^{56} \mathrm{Fe}$ are smaller than the symbols. Data points encircled by the red dashed lines indicate chitons with a red-algae-rich diet, while green dotted lines indicate a predominantly green algae diet. Note that the values for the chitons with a red-algae diet from Washington cluster close together; by contrast, chitons from the same location with a diet of green algae have a larger variance and a lighter isotopic signature. The single value for Tonicella marmorea from Grand Manan Island represents the average of eight homogenized specimens. For comparison, the average for igneous rocks (Beard et al., 2003) is indicated by the vertical grey line, while the range of Fe isotope values reported in the literature for dissolved Fe in surface and shallow (<75 m depth) seawater (Lacan et al., 2008, 2010; John and Adkins 2010, 2012; Rouxel and Auro, 2010; Radic et al., 2011) is represented by the solid blue band at the bottom. Blue squares are published surface seawater isotope analyses of dissolved Fe from locations as close to the chiton sampling sites as available data permit. Data reported by Rouxel and Auro, (2010) for three sites located off the northeastern Atlantic coast of North America are (a) Vineyard Sound on Cape Cod, Massachusetts, USA ( $-0.82 \%$ ); (b) Waquoit Bay on Cape Cod, Massachusetts, USA ( $-0.55 \%$ ); and (c) Connecticut River estuary in Long Island Sound, Connecticut, USA (+0.04\%o). These three sites are located within less than $150 \mathrm{~km}$ distance from each other, on average about $500 \mathrm{~km}$ south of the chiton sampling site at Grand Manan Island, New Brunswick, CA). Data for the North Atlantic (d) (+0.3\%o; sampled about 100 km southeast from Bermuda; John and Adkins, 2010; John and Adkins, 2012) are compared with the Bermuda chiton sampling site. The closest available coastal seawater $\mathrm{Fe}$ isotope data to compare with the Puget Sound chiton sampling site (Washington, USA) is from the San Pedro Basin (e) (0\%o; John and Adkins, 2010), which is located off the Atlantic coast near Los Angeles (California, USA), about $1500 \mathrm{~km}$ south of Puget Sound.

Seawater samples taken at the same site and time of chiton sampling were not available for Fe isotope analyses in this preliminary study. However, to allow for a first-order assessment of biological fractionation during Fe uptake from seawater, we compare our data with published data for Fe isotopes of dissolved $\mathrm{Fe}$ from surface or shallow seawater measured at locations as close as possible to the chiton sampling sites (Fig. 2). For the three regions for which seawater $\mathrm{Fe}$ isotope values are reported (the North Atlantic, the South Atlantic, and the North Pacific), ${ }^{56} \mathrm{Fe}$ of dissolved Fe in surface seawater is more positive than the Fe in chiton teeth: the difference in $\delta^{56} \mathrm{Fe}$ values between seawater and chiton teeth
$\left(\Delta^{56} \mathrm{Fe}_{\text {sw-chiton }}=\delta^{56} \mathrm{Fe}_{\text {seawater }}-\delta^{56} \mathrm{Fe}_{\text {chiton teeth }}\right)$ at the different locations ranges from 0.28 to $1.14 \%$. Thus, overall, $\mathrm{Fe}$ in chiton teeth would seem to be isotopically lighter than $\mathrm{Fe}$ in seawater, suggesting that fractionation processes determine the Fe isotope signatures in chiton teeth. In the following sections we discuss three possible fractionation mechanisms controlling $\mathrm{Fe}$ isotope fractionation in chiton teeth, and these pathways are summarized schematically in Fig. 3.

\subsection{Physiologically controlled Fe isotope fractionation}

One of the possible mechanisms leading to differences between isotopic values in bulk seawater and those in chiton 
Physiologically-controlled fractionation

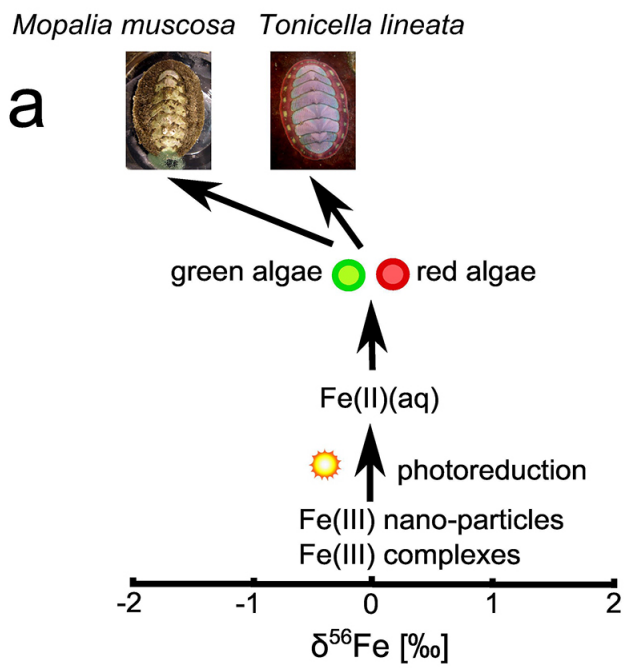

Diet-controlled fractionation

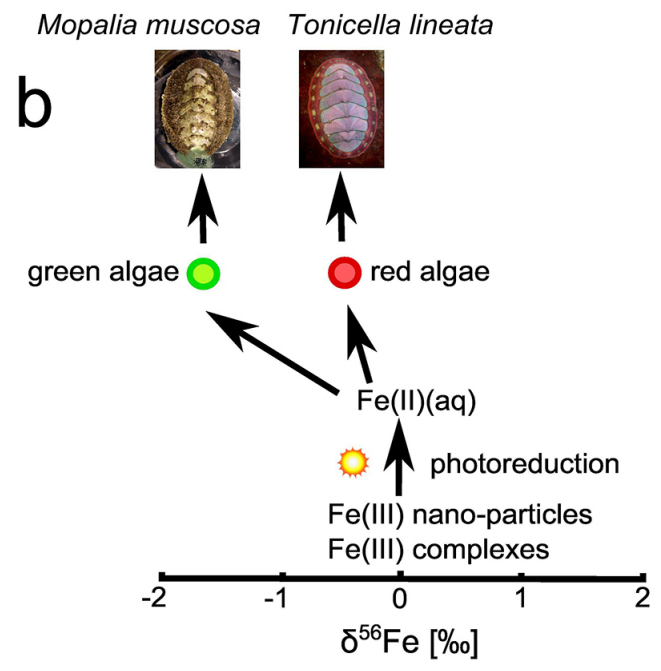

\section{Environmentally-controlled fractionation}

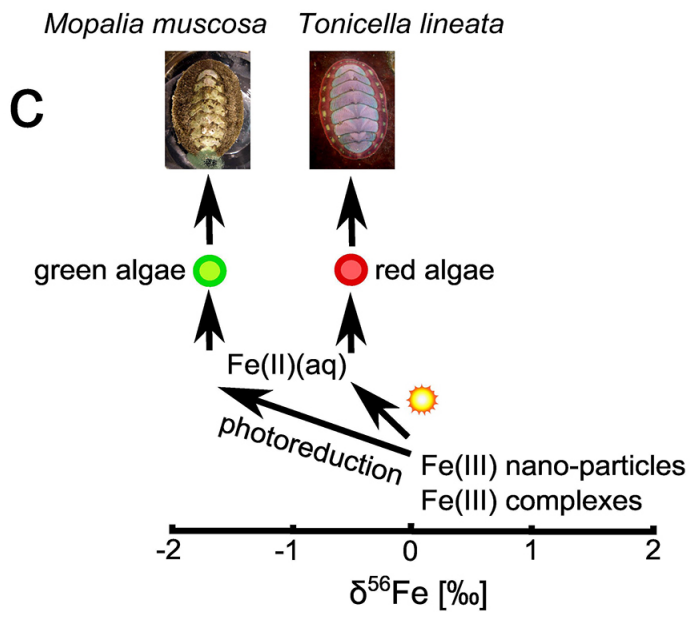

Figure 3. Schematic pathways for isotope fractionation of iron present in seawater and different chiton species. Fractionation could occur during (a) physiologically controlled biomineralization processes within the chitons, (b) fractionation during uptake by algae and subsequent ingestion, and (c) environmentally controlled photoreductive dissolution of Fe complexes and nanoparticles in seawater. The mechanisms are not mutually exclusive and the signatures in the chiton teeth could reflect a combination of different pathways.

teeth could be associated with the mode of biomineralization within the chitons. In addition to magnetite $\left(\mathrm{Fe}_{3} \mathrm{O}_{4}\right)$, chiton radulae contain other $\mathrm{Fe}$ minerals, including goethite $(\alpha$ $\mathrm{FeOOH})$, lepidocrocite $(\gamma-\mathrm{FeOOH})$, and ferrihydrite $\left(\mathrm{Fe}_{2} \mathrm{O}_{3}\right.$. $0.5 \mathrm{H}_{2} \mathrm{O}$ ) (see Brooker and Shaw, 2012, and references therein). To form these minerals, iron originates as ferritin in the haemolymph and is delivered to the superior epithelial cells of the radula sac (Shaw et al., 2009). At a later stage, the ferritin is transferred to an organic matrix, where it is deposited as ferrihydrite (Kim et al., 1989; Brooker et al., 2003). Despite the recent efforts in materials science to better understand Fe biomineralization (e.g. Weaver et al., 2010; Xiao and Yang, 2012), the precise mechanism by which the ferrihydrite precursor is transformed into magnetite remains undetermined. However, this transformation must involve a transition from an $\mathrm{Fe}(\mathrm{III})$ mineral (ferrihydrite) to a mineral that contains both $\mathrm{Fe}(\mathrm{II})$ and $\mathrm{Fe}(\mathrm{III})$ (magnetite). Moreover, changes in redox state can cause relatively large equilibrium 
Fe isotope fractionations ( $\mathrm{Wu}$ et al, 2011; Frierdich et al., 2014); for example, formation of magnetite from aqueous $\mathrm{Fe}(\mathrm{II})$ at $22^{\circ} \mathrm{C}$ leads to a mineral isotopic signature that is around $\sim 1.6 \%$ o heavier, while precipitation of ferrihydrite from aqueous $\mathrm{Fe}$ (II) leads to mineral isotopic values that are between 2.5 and 3.2\%o heavier. Mineralogical compositions in chiton teeth vary from species to species (Lowenstam and Weiner, 1989), and different proportions of the iron-bearing minerals could therefore result in distinct overall isotopic signatures. In future studies, precise measurements of $\mathrm{Fe}$ isotopes in the various mineralogical phases using new techniques, such as laser ablation MC-ICP-MS, could be used to assess fractionation processes during biomineralization.

\subsection{Diet-controlled fractionation}

Another potential mechanism affecting the isotopic values in the chiton teeth is the direct ingestion of iron that is isotopically distinct to iron in seawater. The main source of food for chitons is red and green algae; both types of algae are known to fractionate oxygen and carbon isotopes (Anderson and Arthur, 1983), and it is feasible that Fe isotopes might also be fractionated during uptake by algae. Algae contain high concentrations of Fe (e.g. García-Casal et al., 2007), having developed a range of strategies for creating bioavailable Fe(II) from low-solubility Fe(III) species, including the use of siderophores that facilitate photochemical redox cycling (e.g. Amin et al., 2009). Uptake mechanisms produce strong fractionations in terrestrial plants (von Blanckenburg et al., 2009; Guelke-Stelling and von Blanckenburg, 2012), and if enough $\mathrm{Fe}(\mathrm{II})$ is available, the light isotope may be preferentially absorbed, producing a light $\delta^{56} \mathrm{Fe}$ signal which could depend on algal type.

Curiously, the isotopic values measured in the two chiton species from Puget Sound (Washington, USA) seem to have distinct values. The range in $\delta^{56} \mathrm{Fe}$ values obtained from five individual specimens of $T$. lineata is from -0.83 to $-0.45 \%$ o (mean $\delta^{56} \mathrm{Fe}=-0.65 \pm 0.26 \%$ o, 2 $\sigma$ ); in contrast, more negative $\delta^{56} \mathrm{Fe}$ values ranging from -1.90 to $-0.94 \%$ o (mean $\delta^{56} \mathrm{Fe}=-1.47 \pm 0.98 \%$ o, $2 \sigma$ ) were found for the three specimens of M. muscosa (Fig. 2). As one of the important differences between the two species is their contrasting diets ( $T$. lineata predominantly feeds on red algae, while $M$. muscosa has a diet that includes both green and red algae; Boolootian, 1964; Demopulos, 1975), food sources could account for the different isotopic compositions. Furthermore, the variance associated with the $\delta^{56} \mathrm{Fe}$ signature for M. muscosa is much higher than the variance for T. lineata, which would seem to be consistent with the observation that chitons from the eulittoral zone (intertidal zone), such as M. muscosa, have less specific feeding habits, often ingesting both red and green algae and even animal matter (Boolootian, 1964; Morris et al., 1980).
While isotopic analyses of the different algal types would help evaluate the role of diet in determining the chitons' isotopic signatures, samples were not available for analysis in the current study. However, biological fractionation by algae is supported by an Fe isotope difference measured between phytoplankton and seawater, where an isotopic fractionation of about $0.25 \%$ favouring light isotopes was suggested to occur during uptake by phytoplankton (Bergquist and Boyle, 2006; Radic et al., 2011). Thus, the observed isotopic differences between seawater and chiton teeth could be at least be partially controlled by algal-mediated fractionation.

We note here that direct ingestion of Fe from rocky substrates with different isotopic signatures could also affect the chiton teeth (Lowenstam and Kirschvink, 1996). However, the $\mathrm{Fe}$ isotope composition of crustal igneous rocks is relatively restricted, ranging from about 0 to $+0.4 \%$ in $\delta^{56} \mathrm{Fe}$ (e.g. Beard et al., 2003; Poitrasson and Freydier, 2005), with an average igneous rock composition of $0.1 \pm 0.1 \%$ ( $2 \sigma)$ (Beard et al., 2003). Modern marine sediments, such as terrigenous sediments, turbidite clays, and volcanoclastites, as well as altered oceanic crust, also have a restricted range of $\mathrm{Fe}$ isotope compositions clustered around the average igneous $\delta^{56} \mathrm{Fe}$ value, with variations of less than $0.3 \%$ (e.g. Beard et al., 2003; Rouxel et al., 2003; Fantle and DePaolo, 2004), consistent with the homogeneous Fe isotope composition found in loess and aerosols (Zhu et al. 2000). Thus, $\mathrm{Fe}$ derived from rocky substrates is unlikely to account for the very light Fe isotope values we measured, although confirming this would have required in situ sampling that was beyond the constraints of this preliminary study.

\subsection{Environmentally controlled fractionation}

Environmental conditions in the eulittoral and sublittoral zones are significantly different, and they could exert an additional control on the isotopic pools of bioavailable Fe. In near-surface coastal seawater, dissolved bioavailable Fe(II) is thought to be produced by the photoreduction of $\mathrm{Fe}$ (III) nanoparticles and complexes (e.g. Johnson et al., 1994; Barbeau et al., 2000; Barbeau, 2006; Fan, 2008). Measurements of seawater indicate that $\mathrm{Fe}(\mathrm{II})$ concentrations decrease significantly with depth in the top $10 \mathrm{~m}$ of the water column (e.g. Shaked, 2008), suggesting that photoreduction of Fe(III) to $\mathrm{Fe}(\mathrm{II})$ may be more effective in the shallower eulittoral zone than in the deeper sublittoral zone. Importantly, experiments have shown that the reductive dissolution of iron oxides produces isotopically light Fe(II) (e.g. Wiederhold et al., 2006; Beard et al., 2010), and photoreduction might be expected to produce bioavailable $\mathrm{Fe}(\mathrm{II})$ in seawater that possesses negative $\delta^{56} \mathrm{Fe}$ values. Moreover, differences in levels of photoreduction could produce bioavailable $\mathrm{Fe}(\mathrm{II})$ with light $\delta^{56} \mathrm{Fe}$ values in the eulittoral zone and heavier isotopic values in the deeper sublittoral zone. Importantly, such a mechanism is consistent with the measurements of different chiton species from Puget Sound: Fe isotopes in M. Muscosa from the 
eulittoral zone are indeed lighter than those in T. lineata from the sublittoral zone. Thus, the different isotopic ratios measured in the two species may reflect different water depths and levels of photoreduction in the near-shore environment.

\section{Concluding remarks}

In this paper, we report on the Fe isotopic compositions of chiton radulae from different marine locations in the Pacific and Atlantic oceans. We found a large variation in $\delta^{56} \mathrm{Fe}$ values between the different locations, suggesting that the isotopic compositions may in part be controlled by variations in the local isotopic source signature due to changes in the relative balance of inputs from dissimilatory iron reduction, continental runoff, and non-reductive dissolution of sediments. However, the distinct signatures recorded from two different species analysed from Puget Sound, USA, suggest that $\mathrm{Fe}$ isotopes could be influenced by three main processes: (i) physiologically controlled processes within the chitons that cause species-dependent fractionation, (ii) dietcontrolled variability resulting from different $\mathrm{Fe}$ isotope fractionation in the red and green algal food sources, and (iii) environmentally controlled fractionation that leads to variation in the isotopic signatures of bioavailable $\mathrm{Fe}$ in the different tidal zones.

Clearly the data set presented in the current study possesses a number of limitations. Firstly, the number of chitons in our study is relatively small, a fact that complicates the interpretation of the results. In addition, although a data set of published $\mathrm{Fe}$ isotope values for seawater exists, no $\mathrm{Fe}$ isotope data are available for algae and seawater from the exact locations from which the chiton specimens were collected; moreover, even if values were to be obtained for the present day, it is unclear how relevant such data would be for the samples in this study that were collected decades ago. In view of such constraints, our study must be regarded as a first attempt to tackle the complexities of $\mathrm{Fe}$ isotope fractionation in marine invertebrates, and our findings regarding the Fe isotope fractionation mechanisms are therefore preliminary. To determine the relative significance of the pathways controlling Fe isotopic signatures, a far more extensive sampling campaign - involving in situ measurements of water, rock substrates, algae, and chitons - would be necessary.

Despite the limited data set, the present study nevertheless yields a number of important conclusions. Although the results suggest that $\mathrm{Fe}$ isotopes in biominerals do not necessarily record oceanic values, iron-concentrating organisms such as chitons (polyplacophora) and even limpets (archeogastropods) - which have teeth containing goethite (Lowenstam, 1962b) - could still record the signature of dissolved bioavailable Fe and provide information concerning Fe biogeochemical cycling in near-shore environments. Furthermore, in a similar way to oxygen and nitrogen isotopes, $\mathrm{Fe}$ isotopes could be used to distinguish between the primary sources of $\mathrm{Fe}$ in the diets of different organisms, serving as an additional tool with which to probe ecological systems. Although the difficulties associated with identifying Fe biominerals in the fossil record (Chang and Kirschvink, 1989) currently limit their potential usefulness in reconstructing past conditions, further documentation of Fe isotopes in seawater, algae, and higher organisms is expected to help track the present-day pathways and sources of Fe in marine environments.

Acknowledgements. We thank the associate editor, an anonymous reviewer, and Damien Cardinal for their constructive comments. Douglas Eernisse and Yaela Shaked are also thanked for their helpful advice. S. Emmanuel would like to thank the GermanIsraeli Foundation for Scientific Research and Development for generous financial support via their Young Scientists' Program. In addition, we are grateful to Eric Lazo-Wasem and Lourdes Rojas for providing access to the Yale Peabody Museum invertebrate zoological collection.

Edited by: D. Gillikin

\section{References}

Amin, S. H., Green, D. H., Hart, M. C., Küpper, F. C., Sunda, W. G., and Carrano, C. J.: Photolysis of iron-siderophore chelates promotes bacterial-algal mutualism, P. Natl. Acad. Sci., 106, 17071-17076, 2009.

Anbar, A. D. and Rouxel, O. M.: Metal stable isotopes in paleoceanography. Annu. Rev. Earth Planet Sci., 35, 717-746, 2007.

Anderson, T. F. and Arthur, M. A.: Stable Isotopes of Oxygen and Carbon and Their Application to Sedimentologic and Paleoenvironmental Problems, in: Stable Isotopes in Sedimentary Geology, edited by: Arthur, M. A., Anderson,T. F., Kaplan, I. R., Veizer, J., and Land, L., SEPM, Short Course Notes Vol. 10, Georgia, 1-151, 1983.

Barbeau, K.: Photochemistry of organic iron(III) complexing ligands in oceanic systems, Photochem. Photobiol., 82, 1505-1516, 2006.

Barbeau, K. and Moffett, J.: Laboratory and field studies of colloidal iron oxide dissolution as mediated by phagotrophy and photolysis. Limnol Oceanogr 45, 827-835, 2000.

Beard, B. L., Johnson, C. M., Von Damm, K. L., and Poulson, R. L.: Iron isotope constraints on Fe cycling and mass balance in the oxygenated earth's oceans, Geology, 31, 629-632, 2003a.

Beard, B. L., Johnson, C. M., Skulan, J. L., Nealson, K. H., Cox, L., and Sun, H.: Application of Fe isotopes to tracing the geochemical and biological cycling of Fe, Chem Geol., 195, 87-118, 2003b.

Beard, B. L., Handler, R. M., Scherer, M. M., Wu, L., Czaja, A. D., Heimann, A., and Johnson, C. M.: Iron isotope fractionation between aqueous ferrous iron and goethite, Earth Planet. Sc. Lett., 295, 241-250, 2010.

Bergquist, B. A. and Boyle, E. A.: Iron isotopes in the Amazon River system: weathering and transport signatures, Earth Planet. Sc. Lett., 248, 39-53, 2006. 
Boolootian, R. A.: On growth, feeding and reproduction in the chiton Mopalia muscosa of Santa Monica Bay Helgoland, Mar. Res., 11, 186-199, 1964.

Brantley, S. L., Liermann, L. J., Guynn, R. L., Anbar, A., Icopini, G. A., and Barling, J.: Fe isotopic fractionation during mineral dissolution with and without bacteria, Geochim. Cosmochim. Ac., 68, 3189-3204, 2004.

Brooker, L. R. and Shaw, J. A.: The chiton radula: a unique model for biomineralization studies, in: Advanced Topics in Biomineralization, edited by: Seto, J., 65-84, 2012.

Brooker, L. R., Lee, A. P., Macey, D. J., van Bronswijk, W., and Webb, J.: Multiple-front iron mineralization in chiton teeth (Acanthopleura echinata: Mollusca: Polyplacophora), Mar. Biol., 142, 447-454, 2003.

Chang, S. R. and Kirschvink, J. L.: Magnetofossils, the magnetization of sediments, and the evolution of magnetite biomineralization, Annu. Rev. Earth Pl. Sc., 17, 169-195, 1989.

Coale, K. H., Fitzwater, S. E., Gordon, R. M., Johnson, K. S., and Barber, R. T.: Control of community growth and export production by upwelled iron in the equatorial Pacific Ocean, Nature, 379, 621-624, 1996.

Crosby, H. A., Roden, E. E., Johnson, C. M., and Beard, B. L.: The mechanisms of iron isotope fractionation produced during dissimilatory $\mathrm{Fe}(\mathrm{III})$ reductions by Shewanella putrefaciens and Geobacter sulfurreducens, Geobiology, 8, 169-189, 2007.

De Baar, H. J. W., De Jong, J. T. M., Bakker, D. C. C., Löscher, B. M., Veth, C., Bathmann, U., and Smetacek, V.: Importance of iron for plankton blooms and carbon dioxide drawdown in the Southern Ocean, Nature, 373, 412-415, 1995.

Demopulos, D. A.: Diet, activity and feeding in Tonicella lineate (Wood, 1815), Veliger, 18, 42-46, 1975.

Fan, S. M.: Photochemical and biochemical controls on reactive oxygen and iron speciation in the pelagic surface ocean, Mar. Chem., 109, 152-164, 2008.

Fantle, M. S. and DePaolo, D. J.: Iron isotopic fractionation during continental weathering, Earth Planet. Sc. Lett., 228, 547-562, 2004.

García-Casal, M. N., Pereira, A. C., Leets, I., Ramírez, J., and Quiroga, M. F.: High iron content and bioavailability in humans from four species of marine algae, J. Nutr., 137, 2691-2695, 2007.

Glynn, P. W.: On the Ecology of the Caribbean Chitons Acanthopleura Granulata Gmelin and Chiton Tuberculatus Linni: Density, Mortality, Feeding, Reproduction, and Growth, Smithsonian Institution Press, 1970.

Guelke-Stelling, M. and von Blanckenburg, F.: Fe isotope fractionation caused by translocation of iron during growth of bean and oat as models of strategy I and II plants, Plant Soil, 352, 217-231, 2012.

Homoky, W. B., John, S. G., Conway, T. M., and Mills, R. A.:. Distinct iron isotopic signatures and supply from marine sediment dissolution, Nat. Commun., 4, 2143, doi:10.1038/ncomms3143, 2013

Hotz, K., Augsburger, H., and Walczyk, T.: Isotopic signatures of iron in body tissues as a potential biomarker for iron metabolism, J. Anal. Atom. Spec., 26, 1347-1353, 2011.

John, S. G. and Adkins, J. F.: Analysis of dissolved iron isotopes in seawater, Mar. Chem., 119, 65-76, 2010.
John, S. G. and Adkins, J. F.: The vertical distribution of iron stable isotopes in the North Atlantic near Bermuda, Global Biogeochem. Cy., 26, GB2034, doi:10.1029/2011GB004043, 2012.

Johnson, C. M., Roden, E. E., Welch, S. A., and Beard, B. L.: Experimental constraints on $\mathrm{Fe}$ isotope fractionation during magnetite and $\mathrm{Fe}$ carbonate formation coupled to dissimilatory hydrous ferric oxide reduction, Geochim. Cosmochim. Ac., 69, 963-993, 2005.

Johnson, C. M., Beard, B. L., and Roden, E. E.: The iron isotope fingerprints of redox and biogeochemical cycling in the modern and ancient Earth, Annu. Rev. Earth Planet. Sci., 36, 457-493, 2008.

Johnson, K. S., Coale, K. H., Elrod, V. A., and Tindale, N. W.: Iron photochemistry in seawater from the equatorial Pacific, Mar. Chem., 46, 319-334, 1994.

Kim, K. S., Macey, D. J., Webb, J., and Mann, S.: Iron mineralization in the radula teeth of the chiton Acanthopleura hirtosa, P. R. Soc. Lond. B 237, 335-346, 1989.

Lacan, F., Radic, A., Jeandel, C., Poitrasson, F., Sarthou, G., Pradoux, C., and Freydier, R.: Measurement of the isotopic composition of dissolved iron in the open ocean, Geophys. Res. Lett., 35, L24610, doi:10.1029/2008GL035841, 2008.

Lacan, F., Radic, A., Labatut, M., Jeandel, C., Poitrasson, F., Sarthou, G., Pradoux, C., Chmeleff, J., and Freydier, R.: Highprecision determination of the isotopic composition of dissolved iron in iron depleted seawater by double spike multicollectorICPMS, Anal. Chem., 82, 7103-7111, 2010.

Lowenstam, H. A.: Magnetite in denticle capping in recent chitons (polyplacophora), Geol. Soc. Am. Bull., 73, 435-438, 1962a.

Lowenstam, H. A.: Goethite in radular teeth of recent marine gastropods, Science, 137, 279-280, 1962b.

Lowenstam, H. A. and Kirschvink, J. L.: Iron biomineralization a geobiological perspective, in: Magnetite Biomineralization and Magnetoreception in Organisms, Plenum Press, New York, NY, 5, 3-15, 1996.

Lowenstam, H. A. and Weiner, S.: On Biomineralization, Oxford University Press, Oxford, 1989

Martin, J. H., Gordon, M., and Fitzwater, S. E.: Iron in Antarctic water, Nature, 345, 156-158, 1990

Matthews, A., Zhu, X. K., and O’Nions, R. K.: Kinetic iron stable isotope fractionation between iron(II) and iron(III) complexes in solution, Earth Planet. Sc. Lett., 192, 81-92, 2001.

Matthews, A., Morgans-Bell, H. S., Emmanuel, S., Jenkyns, H. C., Erel, Y., and Halicz, L.: Controls on iron-isotope fractionation in organic-rich sediments (Kimmeridge Clay, Upper Jurassic, southern England), Geochim. Cosmoshim. Ac., 68, 3107-3123, 2004.

Matthews, A., Emmanuel, S., Levi, L., Gvirtzman, H., and Erel, Y.: Kinetic fractionation of $\mathrm{Fe}$ isotopes during transport through a porous quartz medium, Geochim. Cosmochim. Ac., 72, 59085919, 2008.

Morris, R. H., Abbott, D. P., and Haderlie, E. C. Intertidal Invertebrates of California. Stanford University Press, 1980.

Poitrasson, F. and Freydier, R.: Heavy iron isotope composition of granites determined by high resolution MC-ICP-MS, Chem. Geol., 222, 132-147, 2005.

Radic, A., Lacan, F., and Murray, J. W.: Iron isotopes in the seawater of the equatorial Pacific Ocean: new constraints for the oceanic iron cycle, Earth Planet. Sc. Lett., 306, 1-10, 2011. 
Rouxel, O. J. and Auro, M.: Iron isotope variations in coastal seawater determined by multicollector ICP-MS, Geostand. Geoanal. Res., 34, 135-144, 2010.

Rouxel, O., Dobbek, N., Ludden, J., and Fouquet, Y.: Iron isotope fractionation during oceanic crust alteration, Chem. Geol., 202, 155-182, 2003.

Schoenberg, R. and von Blanckenburg, F.: An assessment of the accuracy of stable $\mathrm{Fe}$ isotope ratio measurements on samples with organic and inorganic matrices by high-resolution multicollector ICP-MS, Int J. Mass Spec., 242, 257-272, 2005.

Severmann, S., Johnson, C. M., Beard, B. L., and McManus, J.: The effect of early diagenesis on the $\mathrm{Fe}$ isotope compositions of pore waters and authigenic minerals in continental margin sediments, Geochim. Cosmochim. Ac., 70, 2006-2022, 2006.

Shaked, Y.: Iron redox dynamics in the surface waters of the Gulf of Aqaba, Red Sea, Geochim. Cosmochim. Ac., 72, 1540-1554, 2008.

Sharma, M., Polizatto, M., and Anbar, A. D.: Iron isotopes in hot springs along the Juan de Fuca Ridge, Earth Planet. Sc. Lett., 194, 39-51, 2001.

Shaw, J. A., Macey, D. J., Brooker, L. R., Stockdale, E. J., Saunders, M., and Clode, P. L.: The chiton stylus canal: an element delivery pathway for tooth cusp biomineralization, J. Morph., 270, 588600, 2009.

Staubwasser, M., von Blanckenburg, F., and Schoenberg, R.: Iron isotopes in the early marine diagenetic iron cycle, Geology, 34, 629-632, 2006.

Teutsch, N., Von Gunten, U., Porcelli, D., Cirpka, O. A., and Halliday, A. N.: Adsorption as a cause for iron isotope fractionation in reduced groundwater, Geochim. Cosmochim. Ac., 69, 41754185, 2005.

Towe, K. M. and Lowenstam, H. A.: Ultrastructure and development of iron mineralization in the radular teeth of Cryptochiton stelleri (Mollusca), J. Ultrastruct. Res., 17, 1-13, 1967. von Blanckenburg, F., von Wirén, N., Guelke, M., Weiss, D., and Bullen, T.: Fractionation of metal stable isotopes by higher plants, Elements, 5, 375-380, 2009.

Walczyk, T. and von Blanckenburg, F.: Natural iron isotope variations in human blood, Science, 295, 2065-2066, 2002.

Weaver, J. C., Wang, Q., Miserez, A., Tantuccio, A., Stromberg, R., Bozhilov, K. N., Maxwell, P., Nay, R., Heier, S. T., DiMasi, E., and Kisailus, D.: Analysis of an ultra hard magnetic biomineral in chiton radular teeth, Mater. Today, 13, 42-52, 2010.

Welch, S. A., Beard, B. L., Johnson, C. M., and Braterman, P. S.: Kinetic and equilibrium $\mathrm{Fe}$ isotopic fractionation between aqueous $\mathrm{Fe}(\mathrm{II})$ and $\mathrm{Fe}(\mathrm{III})$, Geochim. Cosmochim. Ac., 67, 4231-4250, 2003.

Weyer, S. and Schwieters, J. B.: High precision Fe isotope measurements with high mass resolution MC-ICPMS, Int. J. Mass. Spec., 226, 355-368, 2003.

Wiederhold, J. G., Kraemer, S. M., Teutsch, N., Borer, P. M., Halliday, A. N., and Kretzschmar, R.: Iron isotope fractionation during proton-promoted, ligand-controlled, and reductive dissolution of goethite, Environ. Sci. Technol., 40, 3787-3793, 2006.

Wu, L., Beard, B. L., Roden, E. E., and Johnson, C. M.: Stable iron isotope fractionation between aqueous Fe (II) and hydrous ferric oxide, Environ. Sci. Technol., 45, 1847-1852, 2011.

Xiao, J. and Yang, S.: Bio-inspired synthesis: understanding and exploitation of the crystallization process from amorphous precursors, Nanoscale, 4, 54-65, 2012.

Zhu, X. K., O’Nions, R. K., Guo, Y. L., and Reynolds, B. C.: Secular variation of iron isotopes in North Atlantic deep water, Science, 287, 2000-2002, 2000.

Zhu, X. K., Guo, Y., Williams, R. J. P., O’Nions, R. K., Matthews, A., Belshaw, N., Canters, G.W., de Waal, E. C., Weser U, Burgess, B. K., and Salvato, B.: Mass fractionation of the transition metal isotopes, Earth Pl. Sc. Lett., 200, 47-62, 2002. 